\title{
The Extent of Effectiveness of Accounting Knowledge in Increasing Accounting Performance of the Jordanian Industrial Public Shareholding Companies
}

\author{
Shaher Falah Al-Aroud ${ }^{1}$ \\ ${ }^{1}$ Assistant Professor, Department Of Accounting, Faculty of Business, ISRA University Amman -Jordan \\ Correspondence: Shaher Falah Al-Aroud, Assistant Professor, Department Of Accounting, Faculty of Business, \\ ISRA University Amman -Jordan
}

Received: March 20, 2017

Accepted: November 9, 2017

Online Published: November 20, 2017

doi:10.5430/afr.v7n1p58

URL: https://doi.org/10.5430/afr.v7n1p58

\begin{abstract}
This study aims to find out the effectiveness of accounting knowledge in strengthening the Accounting performance in Jordanian industrial public shareholding companies. To achieve the objectives of this study, a questionnaire was designed and distributed to the study sample consisting of (47) Finance Managers working for the Jordanian industrial public shareholding corporations. and The study concluded that there is a positive relationship between the accounting knowledge and Accounting performance in the Jordanian industrial public shareholding corporations. It also was concluded that the accounting knowledge has a positive impact on the performance of such corporations. The study recommended the need to create accounting culture that promotes the effective application of accounting knowledge and improves the Accounting performance of the Jordanian industrial public shareholding companies.
\end{abstract}

Keywords: Accounting Knowledge, Accounting Performance, Jordanian industrial public shareholding companies

\section{Introduction}

The financial and business institutions always seek to achieve success and maintain such success and their survival. So, this makes them continually strives to develop, improve and amend their administrative and financial performance, as well as apply revive tools and instruments. The modern enterprise managements seek to get benefit from the accumulated knowledge and expertise besides the solutions developed by researchers. Such efforts lead to the emergent of new opportunities, and the achievement of continuous progress and development. The managements are interested in the employment of accounting knowledge, exert continuous efforts and provide the potentialities and design plans in response of the concerns of improving the administrative and financial performance for achieving an outstanding accounting performance purposes and to respond to the solutions of the accounting problems the enterprises encounter (Banker et al, 2009).

The success of the enterprises in the performance of their missions and duties effectively would assist the enterprises to employ knowledge, because they constitute an important aspect which the financial and accounting performance and success of the enterprises depend on. It provides and meets the other departments of the enterprise needs to creative, well trained and qualified human resources who are well-motivated through educational programs and training workshops, together with developed policies established by the enterprise to elevate and develop the capacity of these human resources. Each department of the organization can achieve its administrative, operational and accounting objectives through such human resources (Kefi and Kalika, 2009). Therefore, this study aims to know the effectiveness of accounting knowledge in increasing the accounting performance in the Jordanian industrial public shareholding corporations.

\section{The Problem of the Study}

Although the accounting knowledge term is important and has positive impacts achieved by the companies in their operations through the adoption of the accounting knowledge concept, but the theoretical, applied and analytical studies in this area are still limited.

The problem of this study focuses on the lack of awareness about the nature of the relationship between accounting knowledge and the Accounting performance in the Jordanian industrial public shareholding companies, which would increase their efficiency and performance. The industrial companies always seek to achieve the maximum levels of 
accounting performance, in addition to developing their functions according to the requirements of the internal and external business environment. Therefore, this study is deemed an attempt to answer the following question: what is the role of accounting knowledge in increasing the Accounting performance in the Jordanian industrial public shareholding corporations? The following sub-questions would arise:

1. How far the Jordanian industrial public shareholding corporations apply the accounting knowledge with its full content (innovation, acquisition, organization and application)?

2. What is the level of the Accounting performance in the Jordanian industrial public shareholding corporations of all its administrative, operational and accounting forms?

\section{The Importance}

The importance of this study emerges from the practical importance as it discusses:

1) It focuses on the subject of accounting knowledge culture and its impact on improving the Accounting performance in Jordanian industrial public shareholding corporations.

2) Assisting the departments of the Jordanian industrial public shareholding companies with the recommendations concluded by the study on the accounting knowledge and Accounting performance.

3) Providing a scientific method to measure the accounting knowledge and Accounting performance to be applied in other area, such as the banks and service companies and other areas.

\section{The Objectives}

The study aims to achieve a set of objectives, including:

1. Recognition of the extent of the availability of accounting knowledge in Jordanian industrial public shareholding corporations.

2. Recognition of the extent of effectiveness of accounting knowledge in boosting the Accounting performance level in the Jordanian industrial public shareholding corporations.

3. Identifying the level of the Accounting performance in the Jordanian industrial public shareholding corporations.

4. Recognition the correlation between accounting knowledge and Accounting performance in the Jordanian industrial public shareholding corporations.

\section{The Theoretical Framework and Previous Studies}

Accounting knowledge is considered as the application of methods, manners, procedures, concepts, criteria or unfamiliar new theories that can be applied for the interpretation, analyzing or solving an accounting problem the management encounters. A creative accountant has outstanding capacities (Brown, et. al, 2013). Accounting knowledge has become today a source of wealth for the organization and economy. When we discuss knowledge fundamentally, the enterprise is interested in accounting knowledge and how to acquire knowledge skills at work and knowledge of business (Wang, 2006). Such knowledge, as indicated by (Lucier and Torsilier, 2005) expresses the ability of understanding by the individuals and organizations to act effectively in the work environment. This knowledge is usually run by the managers and individuals with distinct capabilities, knowledge makers of knowledge and accounting knowledge. Those are in charge of achieving the survival of the organization in a competitive work environment, (Jabal, et al., 2009). Those people and their co-workers work on building the best creative possible accounting knowledge in every aspect of the organization (Al-Zoubi,\&Al-Jariri, 2007). Many managers of industrial organizations are interested in the development of accounting knowledge to the accountants who are serving for such organizations through the encouraging the accountants to raise questions to getting benefit from their managers experience, as it necessary to connect the scientific knowledge they have acquired and the practical application, encouraging team work, liberating thinking and democracy in work environment, as well as developing the spirit of cooperation and participation, in addition to encouraging the personality of the individual and Accounting thinking (Komala, 2015).

Accounting knowledge is deemed one of the important resources in the organizations and a keystone of the organization activities in smart decision making (Al-Shehadeh and Hmeidan 2005) as well as prediction, design, planning, diagnosis and all intuitive judgments (Mousavizadeh, et. al, 2015). It is an expression of the facts, technical terminologies, classifications, limited technologies, laws, theories, calculations and simple statistics (Oliver \& Judy, 2008). Accounting knowledge depends on the data or information that are organized and processed to be able deliver understanding, expertise, accumulated learning and experience when applied to ongoing problem or activity (Feliciano, 2007). Siam (Siam, 2006) argued that accounting knowledge is a cumulative integrated process formed over relatively 
long periods to become available for application to solve certain problems and circumstances. Thus, accounting knowledge is being applied in the interpretation of the information available about a particular situation or case, and to take a decision on how to manage and solve such situation or case(Cao 2013).

The American Society for Training and Development refers to knowledge and creative concept in the form of (Know-how) and (Know-why) and considered it more important to the organization than the tangible assets (Hilali, 2006), while (Q.Cao, et al. 2013) believe that it is possible to link the asset management and information through knowledge management systems. Assets and knowledge management are capable of using technology and convert knowledge into information as well as the transition from the research phase to the application phase for producing goods and provision of services in the organization and developing Accounting performance. Knowledge management system is important in the assessment of the organization performance (Komala, 2102). The accountant's work represents an important role in the organization at all stages of the accounting activity, including recording and operating data, and presenting the output information, and connect the same with the information technology in the organization (Al-Buzour and Hamshari, 2013). Therefore the work of accountant needs to provide him with the necessary technical and accounting knowledge on creativity of solutions of the contemporary accounting issues, represented in the concepts, principles, hypotheses, principles procedures, accounting practices, accounting information system, accounting rules and standards, disclosure, presentation methods, distribution or recording of various expenses, and recognition of revenues. The accountant performs the accounting works because the accountants awareness of the accountants differs from the perception of technical staff (non-accountants) in presenting and processing the data required for the preparation of the required accounting information (Fatiha, 2015).

\subsection{The Difference between Creativity and Innovation of Accounting Knowledge}

Researchers discussed the concept of creativity and innovation from different angles. Many people do not sometimes differentiate between creativity and innovation as they believe that they have the same meaning and there is no difference between the two words. In fact, there is a difference between creativity and innovation. Creativity means ideas described as new, useful and related to the solution of certain problems or assembling or reassembling the known patterns of knowledge in unique forms (Siddigi and Ejeilah, 2007). Innovation means a new product of knowledge and the application of new ideas extensively. Table (1) shows an attempt to differentiate between Creativity and Innovation:

Table 1. The difference between creativity and innovation

\begin{tabular}{|c|c|c|}
\hline Description & Creativity & Innovation \\
\hline 1. Diagnosis & Individual & Teamwork \\
\hline 2. Updating & Prospective & Perpetual and Futuristic \\
\hline 3. Outcome & Potential application and measurement & $\begin{array}{l}\text { Results are guaranteed for application } \\
\text { and measurement }\end{array}$ \\
\hline 4. Type the meeting & Brainstorming and individual ideas & Application of teamwork ideas \\
\hline 5. Thinking type & Conflict between intellectual views & $\begin{array}{l}\text { The convergence of ideas and consensus } \\
\text { around }\end{array}$ \\
\hline 6. Role of inclusiveness & Trends toward thinking, transition to private & $\begin{array}{l}\text { Trends towards application and } \\
\text { transition to participation }\end{array}$ \\
\hline 7. Role in the enterprise & Individual leadership and progressive & $\begin{array}{l}\text { Improves the overall enterprise } \\
\text { performance }\end{array}$ \\
\hline
\end{tabular}

The Accounting performance is the integrated system of the results of the organization works in accounting, administrative and operational works in the light of its interaction with its interior and external environment. It includes the performance of the personnel in their organizational units and the performance of the organizational units in the frame of the general policies of the organization and the performance of the organization in the frame of the economic, social and cultural environment (Banker, et al. 2009).

The Accounting performance is considered as an overall concept and an integrated multifaceted system. So, according to this view, the Accounting performance has several levels; almost three, namely: (Azrigat, 2010):

1. Individual level (the performance of employees, human resources, human capital, intellectual capital).

2. The partial functional level (management and values): the performance of the organizational units within the 
general policy.

3. Macro-level performance: The performance of the enterprise within the frame of economy, social and cultural environment (Harris, Henderson, 2008).

Accounting knowledge and Accounting performance are considered as access to the improvement of performance, productivity, and the pursuit to achieve advanced competitive positions. Therefore, enterprises need to adopt various mechanisms that could enhance the requirements for improving Accounting performance of the organization (Hussein, et al, 2010).

\subsection{Previous Studies}

We shall present the following previous studies relevant to the subject of this study:

The Study conducted by (Mousavizadeh, et, al, 2015), titled "Knowledge Management and the Creation of Business Value". The purpose of the study was to find out which indicators that add value to a business measurement. The study was conducted in the USA. The sample of the study consisted of 142 members of those are serving in the information technology in various areas and sectors of the organization. The study showed that knowledge management has a direct impact on adding a value to the business through the emphasis and support of the senior management of the organization, organizational culture and knowledge management of the organization business.

The Study conducted by (Fatiha, 2015) titled, "the contemporary trends of standardization of accounting knowledge in its theoretical and practical dimensions". It is a modern theoretical study as an attempt to link accounting knowledge management mechanisms and the extent of their impact on accounting practices, in addition to connect the accounting theorizing of accounting knowledge in a modern scientific approach, as well as to link it with the properties of accounting information. The study concluded that there is a need to attempt to unite efforts to link the properties of accounting information, the financial reporting standards and the international accounting standards because they have a direct impact on the effectiveness of the decision maker as well as find out solutions to the contemporary international accounting issues.

The Study conducted by (Komala, 2012), titled "The Influence of the Accounting Managers' Knowledge\& the Top Managements' Supports on the Accounting Information System and Its Impact on the Quality of Accounting Information". It is a case study aimed to recognize Zakat Institutions in Bandung to determine the effect of accounting information system on the quality of accounting information by acquainting to the knowledge of accounting managers and support of top management. The unit of analysis of this study consisted of 31 management institutions of Zakat in Bandung. The results showed that the knowledge of accounting managers and top management support significantly impact on the accounting information systems. Moreover, the quality of accounting information systems has an impact on the quality of accounting information as well.

A study conducted by (Dahmash and Abu Al-Ruz, 2010), titled "The knowledge management between Information technology and accounting rehabilitation". The purpose of this study was to identify and develop the knowledge management and the underlying principles, its relationship to the information technology and its impact on accounting rehabilitation the application of automation systems and standards of the development and application of systems used in business. The two researchers concluded that the information technology is the prime drive to boost the level of knowledge management. This made a significant shift in the new role of the accountants to become more effective in serving the management, face the developments in their profession effectively and efficiently, which is reflected in the success of the enterprises business and exchange and managing knowledge.

The Study conducted by (Jiming, 2008):"Exploring the link between knowledge management performance and firm performance". The purpose of the study was to recognize the extent of connection between knowledge management and evaluation of the Accounting performance. The study showed that the concept of knowledge management comprises qualifications which are deemed an important source of the regulatory resources that specifically contribute to the outstanding performance of the company. The study included (17) companies working in the field of software. The results concluded showed that there is a positive relationship between the knowledge management performance and corporate performance in terms of accounting procedures; such as profit and cost calculation.

\section{What Makes this Study Distinguished?}

Some studies have addressed the knowledge term in general, some addressed knowledge and creativity and some addressed the accounting knowledge with other subjects, such as technology and some addressed knowledge with the strategic performance. This study links accounting knowledge and Accounting performance in the Jordanian industrial public shareholding companies. 


\subsection{Hypotheses}

The following main hypothesis has been formulated and three sub-hypothesis emerged accordingly:

The main hypothesis: There is statistical significant impact at significance level $(\alpha \leq 0.05)$ for the dimensions of the accounting knowledge (innovation, acquisition, organization, and application of accounting knowledge) on the Accounting performance in its dimensions (management performance, operational performance, and accounting performance) in the Jordanian industrial public shareholding corporations.

Sub-hypothesis 1: There is statistical significant impact at significance level $(\alpha \leq 0.05)$ for the dimensions of accounting knowledge (innovation, acquisition, organization, and application of knowledge accounting) on the administrative performance as a dimension of the Accounting performance.

Sub-hypothesis 2: There is statistical significant impact at significant level $(\alpha \leq 0.05)$ for the accounting knowledge dimensions (innovation, acquisition, organization, and application of accounting knowledge) on the operational performance as a dimension of the Accounting performance.

Sub-hypothesis 3: There is statistical significant impact at significant level $(\alpha \leq 0.05)$ for the accounting knowledge dimensions (innovation, acquisition, organization, and application of accounting knowledge) on the financial performance as a dimension of the Accounting performance.

\subsection{Methodology of the Study}

The descriptive research, field analytical, accounting knowledge and Accounting performance approach was adopted in this study. For the analytical field research approach, an inclusive exploratory survey was conducted and the data collected through the answers of the questionnaire distributed to the members of the sample were analyzed. The proper statistical methods were applied to answer the questions of the study and testing the hypotheses.

\subsection{Community of the Study}

The community of the study consists of CFOs (chief financial officers) in all Jordanian industrial public shareholding corporations listed in Amman Stock Exchange, which are (69) corporations for 2015. The companies are classified according to the following subsectors: pharmaceutical and medical industry, chemical industry, manufacture of paper and cardboard, printing, packaging, food and beverage, tobacco and cigarettes, the extractive industries and mining, engineering and construction industry, electrical industry, garment industry, leather, fabric, glass and ceramic industries. (Amman Stock Exchange, 2015).

\subsection{The Sample of the Study}

A random sample was withdrawn, representing $75 \%$ of each sub-sector of the industrial sector. The sample consists of (51) companies and the CFOs in these companies were (51). A questionnaire has been distributed to each member of the sample, (42) questionnaires were returned. (9) Questionnaires were excluded because the data were incomplete, so (42) only were valid for analysis, i.e. representing $(46.4 \%)$ of the questionnaires distributed.

\subsection{The Instrument of the Study}

A questionnaire has been designed to measure the views of the sample on the subject of this study, which is "Accounting Knowledge and Accounting Performance" including the following three parts:

Part I: Contains general information about the characteristics of the sample according to the following demographic variables: job title, age, experience, and professional certificate, and specialization.

Part II:Consists of (20) phrases measure the independent variable of accounting knowledge. The design of this part was made on reliance to (Dahmash, Abu Al-Ruz, 2010 and Shehadah and Hmeidan, 2005) studies. It includes three sub measures for measuring accounting knowledge represented in (innovation, acquisition, organization, and application).

Part III:Consists of (15) phrases that measure the dependent variable of the Accounting performance. This part was designed on reliance to (Azreigat, 1020, Banker et al, 2009) studies. It includes three sub-measures to measure the Accounting performance represented in: (management performance, operational performance, and financial performance). All respondents answers were configured according to five-points Likert scale, namely: always applicable - often applicable - sometimes applicable - rarely applicable - strongly not applicable.

\subsection{Validity of the Instrument}

The questionnaire was reviewed by a number of specialized and expert professors at the universities in Jordan to verify the reliability of the questionnaire paragraphs. Their comments were taken into account and the questionnaire was modified accordingly. 
Reliability of the Study Instrument: Cronpach's alpha coefficient has been extracted to ensure the internal consistency of the questionnaire phrases. Cronbach's alpha coefficient values were as follows:

Schedule 2. The value of the reliability coefficient (internal consistency) for each variable of the study variables

\begin{tabular}{llll}
\hline $\begin{array}{l}\text { Variable } \\
\text { number }\end{array}$ & $\begin{array}{l}\text { Paragraph } \\
\text { numbers }\end{array}$ & Variable name & $\begin{array}{l}\text { Reliability } \\
\text { (Cronbach's Alpha) }\end{array}$ \\
\hline 1 & $1-16$ & Accounting knowledge & 0.8896 \\
2 & $17-31$ & Accounting performance & 0.9085 \\
$1-2$ & $1-31$ & Instrument as a whole & 0.9054 \\
\hline
\end{tabular}

It is noted in table (2) that the reliability coefficients for all study variables were high, as the reliability coefficient for all paragraphs of the instrument was (0.9054), which is high and acceptable ratio for the purpose of this study.

\section{Statistical processing:}

At the completion of data entry by applying SPSS (Statistical package of social sciences) program, the following statistical processes were applied:

1- Arithmetic averages and standard deviations to answer the study questions.

2- Multiple Regression Analysis to test the hypotheses of the study, the impact of the independent variable on the dependent variable.

3- Cronbach's alpha formula for the internal consistency to verify the reliability of the instrument of the study.

\section{Study Model}

The study model consists of independent and dependent variables as follows:

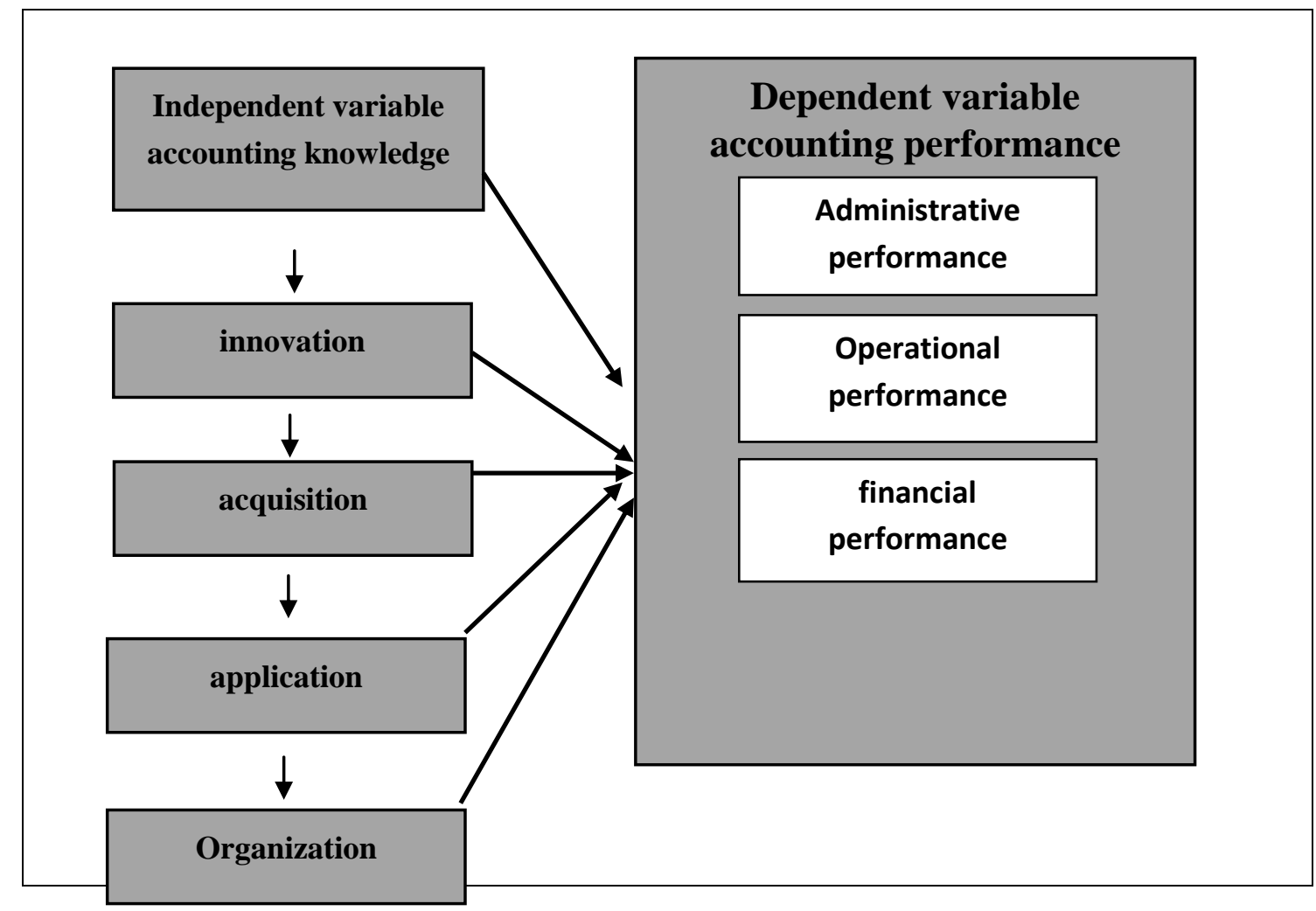

\section{Source: the Author}

\subsection{The Procedural Definitions of the Study}

A. Independent Variable (Accounting Knowledge): Its planned, organized and systematic expertise comprises a set of procedural processes for solving problems that are difficult to be solved in traditional methods. These processes are integrated with each other. This variable comprises the following dimensions: 
1- Innovation: It is the ability of employees to find solutions to the problems they face and learn the skills required by the company. Such skills are scientifically obtained. The views, experience and practices they passed are written to bridge the knowledge gap between departments and divisions and to provide the data to solve the accounting, administrative, and operational problems of the company.

2- Acquisition: It is the employees' ability to acquire knowledge, save and maintain the same for application during practicing business activities of the company from different sources.

3- Knowledge Organization: The capacity of the specialized task forces to apply the accounting knowledge, including recording and classification and documentation of accounting knowledge.

4- Application of Accounting Knowledge: it refers to the ability of the company to benefit from the knowledge and skills acquired in the exercise of duties and reuse and share such skills and knowledge among all workers to improve their skills and raise their creativity and capacity of development to promote the efficiency of the company.

\section{B. The Dependent Variable: The Accounting Performance:}

The standards that help to assess the ability of the company to link its present with future and how it responds to the financial and human resources and use the same in such manner that makes it able to achieve its objectives. The Accounting performance includes:

1. Administrative Performance: it refers to the extent of compliance to the laws, regulations and administrative legislations stipulated in the company and disclose the same in the financial and administrative reports of the company.

2. Operational performance: It expresses the operating activity of the company, business management, and increases its market share while maintaining the quality of its products the same time and measures its performance with pre-established criteria.

3. Financial performance: The capacity of the company to progress, build its competitive position in the market, realization of accounting profits and enhance its accounting performance.

\subsection{The Practical Aspect of the Study}

\section{I: Answer the Questions of the Study:}

First question: What is the level of innovation of accounting knowledge in the Jordanian industrial public shareholding corporations (innovation, acquisition, organization and application)?

Table (3) herein below shows the arithmetic averages of the managers' views of industrial corporations on the level of innovation, acquisition, organization and application of accounting knowledge in the Jordanian industrial public shareholding corporations. The averages were high as the overall average was (3.777). Innovation was ranked first with average (3.94), and acquisition was ranked the last with arithmetic average (3.56).

Table 3. Arithmetic averages and standard deviations of the industrial companies managers answers on the level of innovation, acquisition, organization and application of accounting knowledge

\begin{tabular}{lllll}
\hline Ser. & Paragraph & $\begin{array}{l}\text { Arithmetic } \\
\text { mean }\end{array}$ & $\begin{array}{l}\text { Standard } \\
\text { deviation }\end{array}$ & \% \\
\hline 1 & Innovation level of accounting knowledge & 3.94 & 0.68 & 73.4 \\
2 & Acquisition level of accounting knowledge & 3.56 & 0.65 & 68.9 \\
3 & Organization level of accounting knowledge & 3.60 & 0.64 & 69.1 \\
4 & Application level of accounting knowledge & 3.83 & 0.67 & 72.1 \\
& The overall level of accounting knowledge & 3.77 & 0.68 & 71.5 \\
\hline
\end{tabular}

Second question: what is the level of accounting performance in Jordanian industrial public shareholding corporations (administrative, operational and financial performance)?

Table (4) herein below shows the arithmetic averages of the industrial managers views on the administrative, operational and financial performance in the Jordanian industrial public shareholding companies. The averages were high, as the overall average was (3.67). The administrative performance was ranked first with arithmetic average (3.74) and the operational performance was ranked third with average (3.40). 
Table 4. Arithmetic averages and standard deviations for the answers of the industrial companies' managers on the administrative, operational and financial performance of the Accounting performance in the Jordanian industrial public shareholding companies.

\begin{tabular}{lllll}
\hline T. & Paragraph & $\begin{array}{l}\text { Arithmetic } \\
\text { mean }\end{array}$ & $\begin{array}{l}\text { Standard } \\
\text { deviation }\end{array}$ & \% \\
\hline 1 & The administrative performance level & 3.74 & 0.67 & 71.4 \\
2 & The operational performance level & 3.40 & 0.66 & 68.9 \\
3 & financial performance level & 3.70 & 0.65 & 72.1 \\
& The overall level of Accounting performance & 3.67 & 0.67 & 70.5 \\
\hline
\end{tabular}

\section{II: $\quad$ Statistical Hypotheses Testing}

The Main Hypothesis: There is statistical significant impact at the significance level $(\alpha \leq 0.05)$ for the dimensions of accounting knowledge (innovation, acquisition, organization, and application of accounting knowledge) on the Accounting performance with its aspects (administrative performance, operational performance, and financial performance) in the Jordanian industrial public shareholding corporations.

Schedule 5. Results of multiple regression analysis of testing the impact of various aspects of accounting knowledge on the overall Accounting performance

\begin{tabular}{|c|c|c|c|c|}
\hline Accounting knowledge & Standard error & Beta & $\begin{array}{ll}\text { T } & \text { calculated } \\
\text { value }\end{array}$ & $\begin{array}{l}\text { Significance } \\
\text { level of } t\end{array}$ \\
\hline Innovation of accounting knowledge & 0.042 & 0.205 & $* 4.132$ & 0.000 \\
\hline Acquisition of accounting knowledge & 0.049 & 0.368 & * 8.325 & 0.000 \\
\hline Organization of accounting knowledge & 0.050 & 0.367 & $* 2.140$ & 0.030 \\
\hline Application of accounting knowledge & 0.051 & 0.119 & $* * 2.143$ & 0.033 \\
\hline
\end{tabular}

*has a statistical significance level $(\alpha \leq 0.01)$

** has a statistical significance level $(\alpha \leq 0.05)$

The statistical results set in Table (5) and t-test of the following sub-variables related to (innovation, acquisition, organization, and application of the accounting knowledge) show that they have an impact on the Accounting performance. The calculated value of (t-test) was (4.132. 8.325, 2.140 and 2.756) respectively, which are moral values at significance level $(\alpha \leq 0.01)$. The results indicated that the sub-variable related to (organization and application of knowledge accounting) has less impact on the Accounting performance, as the (t) value calculated was (2.143 and $2.140)$ respectively, which have a statistical significance at level $(\alpha \leq 0.01)$.

Based on the above-mentioned, it is required to reject the null hypothesis, which states that there is no important impact with statistical significance of the variables of the accounting knowledge (innovation and acquisition of accounting knowledge) in the Accounting performance. 


\section{Sub-Hypotheses Testing:}

Table 6. The results of stepwise regression analysis of the test of the impact of the accounting knowledge with its various dimensions on the Accounting performance in the Jordanian industrial and service public shareholding corporations

\begin{tabular}{|c|c|c|c|c|}
\hline Independent & Dependent & $\begin{array}{r}\text { Administrative } \\
\text { performance }\end{array}$ & $\begin{array}{r}\text { Operational } \\
\text { performance }\end{array}$ & $\begin{array}{r}\text { financial } \\
\text { performance }\end{array}$ \\
\hline \multirow{3}{*}{$\begin{array}{l}\text { Innovation } \\
\text { Accounting } \\
\text { Knowledge }\end{array}$} & Beta & 0.259 & 0.254 & 0.22 \\
\hline & t- calculated & *4.691 & $* 3.743$ & *3.979 \\
\hline & T-significance & 0.000 & 0.000 & 0.000 \\
\hline \multirow{3}{*}{$\begin{array}{l}\text { Acquisition of the } \\
\text { Accounting } \\
\text { Knowledge }\end{array}$} & Beta & 0.147 & 0.341 & 0.287 \\
\hline & t- calculated & $* * 2.450$ & $* 6.550$ & $* 5.604$ \\
\hline & T-significance & 0.015 & 0.000 & 0.000 \\
\hline \multirow{3}{*}{$\begin{array}{l}\text { Organization } \\
\text { Accounting } \\
\text { Knowledge }\end{array}$} & Beta & 0.250 & 0.240 & 0.230 \\
\hline & t- calculated & $* 1.600$ & *3.690 & $* 3.800$ \\
\hline & T-significance & 0.000 & 0.000 & 0.000 \\
\hline \multirow{3}{*}{$\begin{array}{l}\text { Application } \\
\text { Accounting } \\
\text { Knowledge }\end{array}$} & Beta & 0.098 & 0.236 & 0.247 \\
\hline & t- calculated & $* * * 1.367$ & $* 4.274$ & $* 3.695$ \\
\hline & T-significance & 0.172 & 0.000 & 0.000 \\
\hline
\end{tabular}

1. Administrative performance: the impact of accounting knowledge (innovation, acquisition, organization and application of accounting knowledge) on the administrative performance.

The statistical results set in Table (6) and t-test of the following sub-variable related to (innovation, acquisition, and organization of the accounting knowledge) show that they are the most variables of accounting knowledge that have impact on the administrative performance. The calculated value of (t-test) was (4.691. 2.450, and 1.600) respectively, which are moral values at significance level $(\alpha \leq 0.01)$. The results indicated that the sub-variable related to (application of knowledge accounting) has no impact on the administrative performance, as the (t) value calculated has no statistical significance at level $(\alpha \leq 0.05)$.

Based on the above-mentioned, it is required to reject the null hypothesis which states that there is no important impact with statistical significance of the accounting knowledge variables (innovation, acquisition and organization of accounting knowledge) in the administrative performance, and to accept the null hypothesis which states that there is no important impact with statistical significance to the variable (application of accounting knowledge) on the administrative performance.

2. The Operational Performance: The impact of accounting knowledge (innovation, acquisition, organization, and application of knowledge accounting) on the operational performance.

The statistical results set in Table (6) and t-test of the following sub-variable related to (innovation, acquisition, organization and application of accounting knowledge) show that these variables have impact on the operational performance, as the $(\mathrm{t})$ calculated value was $(3.743,6.550,3.690$, and 4.274$)$ respectively, which are moral value at the significance level $(\alpha \leq 0.01)$.

Based on the above-mentioned, it is required to reject the null hypothesis which states that there is no important impact with statistical significance of the accounting knowledge variables (innovation, acquisition, organization and application of accounting knowledge) on the operational performance.

3. Financial performance: The impact of accounting knowledge (innovation, acquisition, organization, and 
application of knowledge accounting) on financial performance.

The statistical results set in Table (6) and t-test of the following sub-variable related to (innovation, acquisition, organization and application of accounting knowledge) show that these variables have an impact on the accounting performance, as the (t) calculated value was $(3.979,5.604,3.800$, and 3.695) respectively, which are moral value at the statistical significance level $(\alpha \leq 0.01)$.

Based on the above-mentioned, it is required to reject the null hypothesis which states that there is no important impact with statistical significance of the accounting knowledge variables (innovation, acquisition, organization and application of accounting knowledge) on the financial performance.

\section{Discussion of the Results and Recommendations}

\subsection{Discussion of the Results}

1. Arithmetic averages of the views of managers of industrial firms on the level of accounting knowledge in the Jordanian industrial public shareholding corporations were high, with overall average (3.777). The results indicate that corporate managers focus on innovation of accounting knowledge for the solution of the accounting issues the accountants encounter during their work, as well as exchange and acquire ideas, knowledge, and current accounting innovations, development, documentation and application the same through workshops and electronic publishing, transfer and settle the experience. The results of this study conform to study conducted by (Dahmash and Abu Al-Ruz, 2010), which concluded that the development of the accounting knowledge, knowledge management and accounting rehabilitation are performed through workshops, e-publishing, and information technology.

2. Arithmetic averages of the views of managers of industrial firms on the level of accounting performance in the Jordanian industrial public shareholding corporations were high as the overall average was (3.67). The results show that the corporate managers focus on increasing the efficiency of the administrative performance and clerical works, their organization, recording the accounting processes, keep records and books in order, comply to laws and regulatory legislations of administrative works, organizing the accounting works, records, and accounting books. This study conclusion consistent with the conclusions of a study conducted by (Jiming, 2008), which focused on enhancing the Accounting performance represented in increasing the accounting profit and mitigating the cost calculated.

3. The results showed that the following sub-variables related to (innovation, acquisition, organization, and application of accounting knowledge) have a positive impact on the Accounting performance. This result construes that the workers in Jordanian industrial public shareholding corporations have the intellectual abilities and distinct potential creativity which help them to overcome the obstacles that may encounter without a whimper. It also construes the close relationship between the support of the accounting knowledge management and the promotion of practicing this process, due to the importance of the leadership roles adopted by the senior management. The result conform withthe results of the study conducted by (Komala, 2012) which focused on the support of the senior management on the development and quality of the accounting knowledge.

4. The results show that the sub-variables relevant to (innovation and acquisition of the accounting knowledge) are the most variables of the accounting knowledge that impact the administrative performance. This result explains that the accounting knowledge is one of the incentive effects to achieve the administrative performance, as its aspects contribute to the harmony of interaction and dialogue between individuals.

5. The results showed that the following sub-variables relevant to (creativity, acquisition, organization and application of the accounting knowledge) have an impact on the operational performance. The results construed that the employment of the accounting knowledge contributes to enhancing the operational performance and problems solving within the specific responsibilities of managers.

6. The results showed that the following sub-variables relevant to (innovation, acquisition, organization and application of the accounting knowledge) have an impact on the financial performance. This result is logical as the companies could achieve better competitive advantage due to the accountants' acquisition of characteristics that would lead to mitigate the cost and obtain better accounting performance. This study consistent with the results of the study conducted by (Jiming, 2008) which showed that there is a relationship between the financial performance and accounting profit.

\subsection{Recommendations}

In the light of the conclusions of the study, it is possible to provide a set of meaningful recommendations relevant to the accounting knowledge and its impact on the improvement of the Accounting performance in the Jordanian public 
shareholding companies. These recommendations are:

1) The CFOs should transfer and disseminate their experience about the solutions of accounting problems through scientific entrenching of the vocabularies, registration, records, and sustaining the same among the teamwork in the company.

2) Focusing on training the new and old employees by acquiring the accounting knowledge, application of such knowledge and try to do that.

3) Activation of teamwork approach through the establishment of official and non-official working groups in the management for solving the accounting issues scientifically and systematically due to their positive role in increasing the Accounting performance.

4) The need to work on developing and improving the accounting work environment, documenting the accounting knowledge in the Jordanian public shareholding companies, and keep it constantly updated.

\section{References}

Al-Bizur, Ahmed Iqab, Al- Hamshari, Fatima. (2013). The relationship between IT and accounting knowledge management and rehabilitation in the Jordanian universities, a field study: University of Yarmouk. scientific Journal researches and business, a quarterly magazine, 27(1), part II, Faculty of Commerce and Business Administration, University of Helwan, Egypt.(Arabic).

Al-Khashali. Shaker Jarallah. (2009). knowledge management and its impact on the organizational performance: an empirical study in Jordanian industrial corporations. Arabic magazine of Administration, 29(1), 84-109. (Arabic).

Al-Shehadah, Abdul Razak \& Hmaidan, Abdul Naser. (2005). The role and importance of accounting knowledge in promoting investment culture of the Arab capital markets. Fourth annual international scientific conference, Faculty of Economics and Administration Sciences, Zaytoonah University of Jordan, 26-28 April.(Arabic).

Al-Zoubi, Ali, Al-Jariri, Majed Abdul Aziz. (2007). The role and importance of accounting knowledge in achieving economic competitive advantage in jordanian business and financial organizations (foresightedness). The Fifth Scientific Conference, Faculty of Administrative \& Financial Sciences, Philadelphia University of Jordan, 4-5 July.(Arabic).

Azreigat, Khalid. (2010). the impact of knowledge management on the effectiveness of decision-making in Jordanian public corporations. Studies, Administrative Sciences, 37 (2), 114-134.

Banker, R. D., Chang, H.H., \& Majundar, S. K. (2009). Framework for Analyzing Changes in Strategic Performance. Strategic management Journal, 17(9), 23-36.

Brown, S.A, Dennis, A, Burley, D, Arling, P. (2013). Knowledge Sharing and Knowledge Management System Avoidance: The Role of Knowledge Type and the Social Network in Bypassing an Organizational Knowledge Management System. Journal of the American society for information science and technology, 64(10).

Cao, Qing. Jason Trice. (2013). Investigating the role of business processes and knowledge management systems on performance: A multi-case study approach. International Journal of Production Research, 51(18), 5565-5575. https://doi.org/10.1080/00207543.2013.789145

Coa, Q, Thompson, M A,Triche, J. (2013). Investigating the role of business processes and knowledge management systems on performance: A multi-case study approach. International Journal of Production Research, 51(18).

Dahmash, Naim, Abu Al-Ruz, Afaf. (2010). knowledge management between information technology and accounting knowledge. Journal of Financial Director http://financialmanager.wordpress.com/2010/01/14/ias-5/

Fatiha, Sapho. (2015). contemporary trends of standardization of accounting knowledge in its theoretical and practical dimensions, Academy of social studies and Humanities, economic and legal sciences, No. 13, Janfi, p. 47-57, Algeria.

Feliciano, J. L. (2007). The Success Criteria for Implementing Knowledge Management Systems in an Organization, $\mathrm{Ph} . \mathrm{D}$ Dissertation, Pace University, (USA).

Harris, J. \& A. Henderson. (2008). a Better Mythology for System Design" Proceeding of the Conference on Human Factors in Computing Systems( New York: ACM Press, pp. 88 - 95 ).

Hilali, Hussein Mustafa. (2006). Knowledge management between the accounting knowledge and innovation of Accountants, a conference on the roles of accountants and Auditors in management decisions and development of resources, the Arab Organization for Administrative Development, Arabic League, Cairo, Egypt, 2006. 
Hussein, Iftikhar. (2010). Knowledge Management For SMEs In Developing Countries", Journal of Knowledge Management Practice, Vol. 11, (2) Reviewing at http://www.tlainc.com/articl228.htm

Jabal, Aladdin, Khalid Qutteini, KindahKhitatah (2009): "The role of accounting knowledge in predicting the financial failure of the companies: applied study on textile companies in the public sector in Syria, Development of Al-Rafedein magazine, Vol. (31) No. (95), p. 297-317, Faculty of Administration and Economy, University of Mosul, Iraq.

Jiming, wu. (2008) "Exploringthe link between knowledge Management performance and firm performance. Unpublished Doctoral dissertation, University of Kentucky. USA.

Kefi, H., \& Kalika, M. (2009). Survery of Strategic Alignment Impact on Strategic Performance in International European Companies. Proceeding of the 38th Hawaii International Conference on System Sciences.

Komala, Adehrotana. (2012). The Influence of the Accounting Mangers' Knowledge \& the Top Managements' Supports on the Accounting Information System and Its Impact On The Quality Of Accounting Information: A case OF Zakat Institutions in Bandung.

Lucier, W .Torsilier R. (2005). Playing An Integral Role In Knowledge Management. Information System Management, 17(4), 46-61.

Mas'oud Siddiqui, Mohammad Ejeilah. (2007). The importance of accounting knowledge in achieving competitive economic organizations - foresightedness, the second scientific conference, ISRA University, Amman.

Mousavizadeh, MO, Ryan, SH, Harden, G, Widsor, J. (2015). Knowledge Management and the Creation Of Business Value. Journal of Computer Information Systems, 55(4), Summer. https://doi.org/10.1080/08874417.2015.11645785

Oliver, Judy. (2008). Knowledge Management Practices To Support Continuous Improvement. Journal of Knowledge Management Practice, 9(4).

Siam. Z, Walid. (2006). The Extent of Awareness of the Importance of Accounting Knowledge Management in the Jordanian Industrial Shareholding Companies. Journal Dirasat, Administrative Sciences, 33(1).

Wang, J. (2006). Knowledge Management In Innovation Teams: A Case Study Of An IT Development Institute in Taiwan, Ph.D. Dissertation, University of Southampton (United Kingdom). 